\title{
State and Conservancy of Water Resources When Mining
}

\author{
Alla Ignatova ${ }^{1}$, Andrey Papin ${ }^{1}$, and Vyacheslav Solodov ${ }^{1}$ \\ ${ }^{1}$ T.F. Gorbachev Kuzbass State Technical University, 650000, Kemerovo, Russian Federation
}

\begin{abstract}
Coal mining and processing is associated with environmental pollution at all stages. The impact is on all components of the biosphere. The analysis of the current state of minor rivers of the Kemerovo Region, flowing in areas of active mining operation, is presented in the article. The activities of coal mining enterprises, aimed at reducing the negative impact on water resources, are considered.
\end{abstract}

\section{Introduction}

The impact of mining in general and coal mining in particular on the environment is multifaceted and concerns all components of the biosphere. Emissions of pollutants (dust, methane, oxides of carbon, nitrogen and sulfur), wastewater discharges into water bodies and terrain, solid waste storage on the earth's surface cause irreparable damage to the natural environment, have a direct impact on the health of the population of coal mining regions, radically transforms the terrestrial landscape, turning it into a kind of lunar surface $[1-3]$.

At the same time, the use of coal in the energy sector turned out to be several times cheaper than natural gas, and the use of coal in metallurgy and the production of various materials increased. All this allows coal mining companies to increase coal production. Currently, Russia is ranked 6th in the world in terms of coal production and 3rd in its exports [6-10].

\section{Materials and Methods}

The state of a number of minor rivers of the Kemerovo region belonging to the VerkhObskoy River Basin and flowing in areas of active open cut mining (the Prokopievsky coal deposit, the Severo-Taldinsky coal deposit), near the settlements: Prokopyevsk, Novokuznetsk, Belovo, Kiselevsky urban district, villages of Kotino, Kyrgay, Bolshaya Talda, Malaya Talda, villages of Maganak, Severny Maganak, Yasnaya Polyana, Uspenka, is analyzed in this paper. The activities of coal mining enterprises, aimed at reducing the negative impact on water resources, are also considered. 


\section{Results and discussion}

The research was focused on the rivers that are receivers of wastewater from the mining industry: Tagarysh, Kyrgay, Maganak, Uskat, Chernovoy Naryk, Talda, etc. Coal mining wastewater contains inorganic ions $\mathrm{Ca}^{2+}, \mathrm{Mg}^{2+}, \mathrm{Na}^{+}, \mathrm{HCO}^{3-}, \mathrm{Cl}^{-}, \mathrm{SO}_{4}^{2-}, \mathrm{Si}^{4+}, \mathrm{NO}^{2-}, \mathrm{NO}^{3-}$, $\mathrm{NH}^{4+}, \mathrm{Fe}^{2+}, \mathrm{Fe}^{3+}$, microcomponents ( $\mathrm{Pb}, \mathrm{Zn}, \mathrm{Mn}, \mathrm{F}, \mathrm{Cu}, \mathrm{Cd}, \mathrm{As}, \mathrm{Se}, \mathrm{Sr}, \mathrm{Li}, \mathrm{Ba}, \mathrm{Co}$ ), organic compounds - phenols, petroleum products, are contaminated with microflora, particles of rock and minerals [4-5].

The Tagarysh River flows from north to south at a distance of $0.5 \mathrm{~km}$ from the eastern border of the designed facility. According to the Verkh-Obskoy River Basin Water Authority, issued from the State Water Registry, the Tagarysh River is a left-sided tributary of the Uskat River (a tributary of the Tom River) and flows into it at a distance of $11.0 \mathrm{~km}$ from the mouth. The length of the river is $16.2 \mathrm{~km}$; the catchment area is $45.6 \mathrm{~km}^{2}$ (according to the Letter of the Water Resources Department for the Kemerovo Region of the Verkh-Obskoy River Basin Water Authority No. 10-32/423 of April 12, 2017, "On Providing Information from the State Water Register"). The river is flat all over, the course is meandering, and the average flow velocity is $0.24 \mathrm{~m} / \mathrm{s}$. The surface of the catchment area is transformed by mining. The river flows in a ravine with high (up to $30.0 \mathrm{~m}$ ) steep slopes. The width of the valley is from 50.0 to $100.0-120.0 \mathrm{~m}$. The channel is unexpressed, tortuous and narrow (width is 1.0-2.0 m), heavily overgrown with shrubs.

In the upper reaches of the Tagarysh River, open-pit coal mining operations are conducted, and the dump of the OOO "Open pit Yuzhny" is located. According to Article 65 of the "Water Code of the Russian Federation" (2006), the width of the water protection zone of the Tagarysh River is $100 \mathrm{~m}$.

The Chernovoy Naryk River is the left tributary of the Tom River. It flows into the river Tom at a distance of $505 \mathrm{~km}$ from the mouth. The length of the river is $106 \mathrm{~km}$; the catchment area is $623 \mathrm{~km}^{2}$. The river flows first from north to south, and then turns to the north near the Uskovo village. The floodplain of the river is two-sided, meadow, $300-500 \mathrm{~m}$ wide, in some places meadow lands are swamped. According to Article 65 of the "Water Code of the Russian Federation" (2006), the width of the water protection zone of the Chernovoy Naryk River is $200 \mathrm{~m}$.

The Yelanny Naryk River is a right-bank tributary of the Chernovoy Naryk River, flowing in it at a distance of $55 \mathrm{~km}$ from the mouth. A number of ponds of various sizes were built on the river for the needs of coal mining enterprises. The catchment area and the river bed are significantly destroyed by open cut coal mining. At a distance of $14 \mathrm{~km}$ from the source, the bed of the Yelanny Naryk River is diverted from the pond to the Chernovoy Naryk River. The source of the river is changed, and the length of the river is currently 24 $\mathrm{km}$.

The Talda River flows into the Kyrgay River at a distance of $14 \mathrm{~km}$ from the mouth. The length of the stream is $26 \mathrm{~km}$. The surface of the catchment in the middle reaches of the river was also significantly transformed by mining operations.

The Uskat River is a left tributary of the Tom River and flows into it at a distance of $546 \mathrm{~km}$ from the mouth. The total catchment area is $1,500 \mathrm{~km}^{2}$; the length of the river is 43 $\mathrm{km}$. The Uskat River is formed from the confluence of the Priamoy Uskat River and Krivoy Uskat River, originating on the eastern slopes of the Salair Ridge, and retains the south-east direction of the current throughout. The valley of the Uskat River is wide, well developed, having gentle open slopes. According to Article 65 of the "Water Code of the Russian Federation" (2006), width of the water protection zone of the Uskat River is $100 \mathrm{~m}$.

The river Kyrgay is a second order left tributary of the Tom River through the Uskat River. The length of the river is $46 \mathrm{~km}$; the catchment area is $251 \mathrm{~km}^{2}$. The channel of the river is meandering, the average flow velocity is $0.19 \mathrm{~m} / \mathrm{s}$, the average flow depth is $0.32 \mathrm{~m}$. 
The Kyrgay River is formed from the confluence of the Stepnoy Kyrgay River and Taezhny Kurgay River, which originate on the slopes of the Karakan and Abinsk ranges, and merge into one streambed at the Kyrgay village. It falls into the Uskat River on the left at a distance of $22 \mathrm{~km}$ from the mouth. According to Article 65 of the "Water Code of the Russian Federation" (2006), the width of the water protection zone of the Uskat River is $100 \mathrm{~m}$.

According to the information provided by the Kemerovo department of state control, supervision and protection of aquatic biological resources and their habitat the Tagarysh River is a fishery water body of the second category (Letter No. 11-61/26 of April 14, 2017 of the Kemerovo department of state control, supervision and protection of aquatic biological resources and their habitat "On the fishery category of the Tagarysh River").

The assessment of river contamination was carried out according to monitoring data provided by ZAO "Taldskoe Yuzhnoye Mine Management" and water samples examined during surveys. The results of laboratory tests of samples taken in the Tagarysh River conducted by OOO "RusInteCo" testing laboratory center are shown in Table 1 (Test Report No. 179/2017-X-9 dated 10/09/2017).

Table 1. The results of laboratory tests of the samples taken in the Tagarysh River.

\begin{tabular}{|c|c|c|c|}
\hline \multirow{2}{*}{ Indicator } & \multirow{2}{*}{$\begin{array}{c}\text { Units of } \\
\text { measurement }\end{array}$} & Test results & \multirow{2}{*}{$\begin{array}{c}\text { Standard for } \\
\text { fishery water } \\
\text { bodies }\end{array}$} \\
\hline & & $\begin{array}{c}\text { Sample } \\
\text { (river Tagarysh) }\end{array}$ & \\
\hline Potassium $(\mathrm{K})$ & $\mathrm{mg} / \mathrm{dm}^{3}$ & 0.27 & 50.0 \\
\hline Sodium $(\mathrm{Na})$ & $\mathrm{mg} / \mathrm{dm}^{3}$ & 4.99 & 120.0 \\
\hline Calcium $\left(\mathrm{Ca}^{2+}\right)$ & $\mathrm{mg} / \mathrm{dm}^{3}$ & 46.24 & 180.0 \\
\hline Magnesium $\left(\mathrm{Mg}^{2+}\right)$ & $\mathrm{mg} / \mathrm{dm}^{3}$ & 9.16 & 40.0 \\
\hline Strontium (Sr) & $\mathrm{mg} / \mathrm{dm}^{3}$ & 0.25 & 0.4 \\
\hline Barium $(\mathrm{Ba})$ & $\mathrm{mg} / \mathrm{dm}^{3}$ & 0.05 & 0.74 \\
\hline Ammonium $\left(\mathrm{NH}_{4}\right)^{+}$ & $\mathrm{mg} / \mathrm{dm}^{3}$ & 0.41 & 0.5 \\
\hline Sulfate $\left(\mathrm{SO}_{4}\right)^{2-}$ & $\mathrm{mg} / \mathrm{dm}^{3}$ & 11.87 & 100.0 \\
\hline Chloride $\left(\mathrm{CL}^{-}\right)$ & $\mathrm{mg} / \mathrm{dm}^{3}$ & 1.12 & 300.0 \\
\hline Nitrate $\left(\mathrm{NO}_{3}\right)^{-}$ & $\mathrm{mg} / \mathrm{dm}^{3}$ & 20.74 & 40.0 \\
\hline Nitrite $\left(\mathrm{NO}_{2}\right)^{-}$ & $\mathrm{mg} / \mathrm{dm}^{3}$ & 0.20 & 0.08 \\
\hline Fluorides $(\mathrm{F})^{-}$ & $\mathrm{mg} / \mathrm{dm}^{3}$ & 0.16 & 0.75 \\
\hline Phosphates $\left(\mathrm{PO}_{3}\right)^{3-}$ & $\mathrm{mg} / \mathrm{dm}^{3}$ & 0.08 & 0.01 \\
\hline $\mathrm{pH}$ value & ед.ph & 7.50 & $6.0-9.0$ \\
\hline Salt content & $\mathrm{mg} / \mathrm{dm}^{3}$ & 639.28 & 1000 \\
\hline Turbidity & FTU & 0 & 2.6 \\
\hline Odour & point & 0 & 2 \\
\hline Flavour & point & 0 & 0 \\
\hline Ferrum $\left(\mathrm{Fe}^{2+}\right)$ & $\mathrm{mg} / \mathrm{dm}^{3}$ & 0.18 & 0.3 \\
\hline Lead & $\mathrm{mg} / \mathrm{dm}^{3}$ & - & 0.006 \\
\hline Zinc & $\mathrm{mg} / \mathrm{dm}^{3}$ & - & 0.01 \\
\hline Manganese & $\mathrm{mg} / \mathrm{dm}^{3}$ & 0.0040 & 0.01 \\
\hline Copper & $\mathrm{mg} / \mathrm{dm}^{3}$ & - & 0.001 \\
\hline Arsenic & $\mathrm{mg} / \mathrm{dm}^{3}$ & 0.0006 & 0.05 \\
\hline
\end{tabular}

Exceeded maximal permissible concentrations of nitrite ion, phosphate ion for fishery water bodies are observed. Upstream at a distance of about $2 \mathrm{~km}$ there is a discharge of treated mine and surface waters into the Tagarysh River by AO "Taldskoe Yuzhnoye Mine Management", where water samples are taken within the framework of industrial environmental monitoring.

In the Tagarysh River water samples, taken for microbiological analysis, excess hygienic ratings of $\mathrm{OCB}, \mathrm{TCB}$, coliphages, as well as helminth eggs and cysts of 
pathogenic protozoa were not found (Laboratory Test Report No. 20202 dated 04/10/2017. Tests were performed by the "Center for Hygiene and Epidemiology in the Kemerovo Region" in Novokuznetsk and Novokuznetsk district).

In the upper reaches of the Tagarysh River there are a number of treatment facilities of OOO "Resurs" and AO "Taldskoe Yuzhnoye Mine Management".

During the construction of the waste dump of coal processing plant "Taldinskaya", dump wastewater treatment the newly designed facilities is planned. Waste coal dump surface wastewater will be treated due to plain settling in the settling pond and filtering through the filter dam (artificial filtering mass). Treated wastewater is planned to be discharged into the Tagarysh River during the period of maximum water inflow. Treated wastewater will also be used for irrigation of the dump and the roads. It is planned to install booms with the sorbing element "Unisorb" to remove floating oil products in the settling pond.

The Kyrgay River is a second order left tributary of the Tom River through the Uskat River. The length of the river is $46 \mathrm{~km}$; the catchment area is $1040 \mathrm{~km}^{2}$ (Copy of the Letter No. 13-14/259 of November 12, 2013 on the fishery characteristic of the Kyrgay River of the Kemerovo branch of the "Verkh-Obskoy River Basin Department for Fisheries and the Conservation of Aquatic Biological Resources").

Background concentrations of pollutants in the Kyrgay River are given on the basis of the Letter from the Novokuznetsk Hydro-meteorological Observatory and are presented in the Table (Copy of the Letter No. 1111 of the Novokuznetsk Hydro-meteorological Observatory of December, 12, 2015 on the Kyrgay River (On background concentrations of pollutants). The Kyrgay River background suspended matter concentration is $17.4 \mathrm{mg} / \mathrm{dm}^{3}$ (Letter of the Novokuznetsk Hydro-meteorological Laboratory on background concentrations No. 789 of July 21, 2017).

According to the letter of the Municipal Property Management Committee of the Prokopievsky municipal district, the Kyrgay River is an object of public and recreational water use and is used for recreation of the population (fishing) and public water supply (watering livestock) (Copy of the Letter the Municipal Property Management Committee of the Prokopievsky municipal district No. 843 of April 04, 2016).

The Kyrgay River is defined as a category 1 fishery water body (Copy of the Letter on the fishery category of the Kyrgay River of the Kemerovo department of state control, supervision and protection of aquatic biological resources and their habitat of the VerkhObskoy Regional Administration of the Federal Agency on fishing No. 11-61/481 of December 11, 2013).

OOO "V.I. Cheremnov Open Pit" discharges sewage into the Kyrgay River, according to the approved standards for permissible discharge of December 29, 2012 (Permit for wastewater discharge No. 0891/PPT/CC-06.2018 of June 19, 2018 On making water body available for use).

As a result of engineering and environmental surveys conducted by the engineering surveys of OOO "Sibniiugleobogashcheniye", surface water samples were taken at a distance of $500 \mathrm{~m}$ up and down from the discharge point, as well as water before and after the treatment facilities. Currently, sewage treatment plants consist of a single process line. The structure of this line includes: settler, filtering mass, treated water pond, discharge line, treated water release. The treatment facilities were commissioned on October 22, 2010 (Commissioning Certificate No. 173 of October 22, 2010).

Sampling was carried out according to GOST 31861-2012 "Water. General requirements for sampling". The results of laboratory tests are compared with the background concentrations of the river and with the maximal permissible concentrations for fishery water bodies in the Table. The tests were carried out by the Eco-analytical test 
laboratory of OOO "Ecoanalytica" (Influent Water Test Report No. 310/A dated 26/06/ 2017).

The results of the analysis of water samples suggest that the indicators of water quality are highly variable. The level of the Kyrgay River pollution in many respects does not correspond to the Maximal permissible concentrations established for fishery water bodies.

Table 2. Results of chemical analysis of surface water samples.

\begin{tabular}{|c|c|c|c|c|}
\hline \multirow{2}{*}{ Analytes } & \multicolumn{2}{|c|}{ Surface water } & \multirow{2}{*}{ 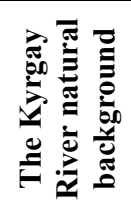 } & \multirow{2}{*}{$\begin{array}{c}\text { Maximal } \\
\text { permissible } \\
\text { concentration } \\
\text { for fishery } \\
\text { water bodies } \\
\text { mg/dm3 }\end{array}$} \\
\hline & Downsream & Upstream & & \\
\hline Explosives & 223 & 175 & 18.2 & 7.55 \\
\hline Sulphates & 23 & Less than 20 & 43.8 & 100 \\
\hline $\begin{array}{l}\text { Chemical } \\
\text { oxygen } \\
\text { demand }\end{array}$ & 10.78 & 19.20 & - & 30 \\
\hline $\begin{array}{l}\text { Biochemical } \\
\text { oxygen } \\
\text { demand }_{5}\end{array}$ & 3.18 & 3.47 & 3.38 & 4 \\
\hline $\begin{array}{l}\text { Ammonium } \\
\text { nitrogen }\end{array}$ & 3.250 & 2.310 & 0.18 & 0.4 \\
\hline $\begin{array}{l}\text { Nitrite } \\
\text { nitrogen }\end{array}$ & 0.02 & 0.011 & 0.033 & 0.08 \\
\hline $\begin{array}{l}\text { Nitrate } \\
\text { nitrogen }\end{array}$ & 2.10 & 3.26 & 1.64 & 9.0 \\
\hline $\begin{array}{l}\text { Phosphate } \\
\text { phosphorus }\end{array}$ & Less than 0.05 & Less than 0.05 & 0.012 & 0.61 \\
\hline Total ferrum & 4.06 & 2.93 & 0.08 & 0.1 \\
\hline Cuprum & 0.0238 & 0.0047 & 0.002 & 0.001 \\
\hline Nickel & 0.0130 & Less than 0.001 & - & 0.01 \\
\hline Phenols & 0.0051 & 0.0048 & 0.002 & 0.1 \\
\hline $\begin{array}{l}\text { Synthetic } \\
\text { surface active } \\
\text { substance }\end{array}$ & 0.0154 & 0.0157 & 0.02 & 0.1 \\
\hline $\begin{array}{l}\text { Dissolved } \\
\text { oxygen }\end{array}$ & 9.4 & 9.8 & - & 5.0 \\
\hline Manganese & 0.366 & 0.301 & 0.006 & 0.01 \\
\hline Zinc & 0.0165 & 0.0087 & 0.007 & 0.01 \\
\hline Transparency & 2.50 & 2.60 & - & 20.0 \\
\hline
\end{tabular}

According to the biotesting results (Test Reports No. 114B, 115B, 116B, 117B dated April 26, 2017), water before treatment has an acute toxic effect on the test organisms used. Water after treatment does not have a toxic effect on algae Scenedesmus quadricauda, but it cannot be considered harmless in terms of "toxicity". Natural water down and up the wastewater discharge does not have an acute toxic effect on the test organisms used.

The Maganak River is a second order left tributary of the Tom River through the Aba River. The length of the river is about $14 \mathrm{~km}$, the bottom of the river is sandy and rocky, sometimes heavily silted. The width of the water protection zone of the Maganak River in accordance with Article 65 of the "Water Code of the Russian Federation" (2006) is $100 \mathrm{~m}$. Information of the Maganak River from the State Water Register is presented on the basis of the Letter of the Water Resources Department for the Kemerovo Region of the VerkhObskoy River Basin Water Authority No. 10-31/1444-H of November 18, 2013. 
The catchment area of the Maganak River is disturbed. According to the hydrological exploration degree, the survey area belongs to unexplored areas, as the water body of the Maganak River is not observed.

A section of the Maganak River flows along an artificial channel, made in a reinforced sewer.

According to the Letter No. 11-61/38 of January 23, 2013 of the Kemerovo department of state control, supervision and protection of aquatic biological resources and their habitat of the Verkh-Obskoy Regional Administration of the Federal Agency on fishing, the Maganak River is defined as a fishery water body of the second category.

According to data from the State Water Register, the Maganak River has two wastewater discharges: Municipal Unitary Enterprise "Housing Services", the discharge point distance from the mouth is $2 \mathrm{~km}$; OAO "Production Association Vodokanal", the distance from the mouth is $8 \mathrm{~km}$.

Laboratory tests were conducted in accredited laboratories: Center for Laboratory Tests and Examination "SIDIUS", "Center for Laboratory Analysis and Technical Measurements for the Siberian Federal District", "Center for Hygiene and Epidemiology for Railway Transport".

Physical and chemical characteristics of the Maganak River is reflected in the Records of Measurement of Physical and Chemical Indicators No. 071-B-1 dated 25/06/2018, No. 071-B-2 dated 25/06/2018 and No. 071-B-3 dated 25/06/2018 (the Center for Laboratory Tests and Examination "SIDIUS").

The sample of the Maganak River surface water according to the studied physical and chemical parameters does not meet the quality standards for fishery water bodies according to the following indicators: oil products, total iron, zinc, copper, manganese, nickel, mercury and phosphate ion.

On the territory of designed facilities, 1 water sample was taken from a surface source (the Maganak River) (Surface water (B-1) Sample Test Record No. 071-Rf-B-1 dated 25/06/2018 of the Center for Laboratory Tests and Examination "SIDIUS").

According to the results of surface water tests, the total volumetric activity of alphaemitting radionuclides exceeds the regulated $0.2 \mathrm{~Bq} / \mathrm{kg}$ rate (Sanitary Regulations and Standards 2.6.1.2523-09 (НРБ-99/2009), the total volumetric activity of beta-emitting radionuclides does not exceed the regulated $1.0 \mathrm{~Bq} / \mathrm{kg}$ rate according to Sanitary Regulations and Standards 2.1.5.980-00. The bottom sediments samples were taken in layers from the surface watercourse in the survey area to determine radiation characteristics and regulatory compliance (Bottom Sediment Test Record (the Maganak River) No. 071Рф-ДО-1, dated 25/06/2018 of the Center for Laboratory Tests and Examination "SIDIUS". The specific activity in the sediment sample was $71.6 \mathrm{~Bq} / \mathrm{kg}$. Samples are classified as class 1 according to the radiation safety standards of Russia (НРБ-99/2009) (effective specific activity not exceeding $370 \mathrm{~Bq} / \mathrm{kg}$ ).

The results of microbiological tests of the Maganak River surface water samples are presented in the Laboratory Test Record No. 02213 dated 04/06/2018. The analysis of the surface water samples was carried out by the testing center of the "Center for Hygiene and Epidemiology for Railway Transport".

The presented sample of the Maganak River surface water according to the microbiological indicators tested does not meet the requirements of Sanitary Regulations and Standards 2.1.4.1175-02 "Hygienic requirements for the quality of water from decentralized water supply. Sanitary protection of sources".

OOO "Open pit "Berezovsky" constructed treatment facilities to ensure the treatment of incoming mine wastewater from the site of "Severny Maganak mine field". Wastewater treatment facilities are designed to remove suspended particles, oil products, heavy metals, sulfates, iron and other substances from incoming wastewater. The efficiency of wastewater 
treatment is achieved by clarification in the receiving tank and filtration through a filtering mass, made from crushed trap rock with layers of sorbents. Estimated capacity of treatment facilities is $1400 \mathrm{~m}^{3} / \mathrm{h}$.

Treated wastewater is supposed to be discharged into the Maganak River as well as treated wastewater should be used for watering roads and de-dusting surfaces. For water intake, a platform is provided for filling street sprinkler with water.

\section{Conclusion}

The analysis conducted shows the ambiguity of the situation in the area of water use in the coal mining areas of the Kemerovo Region. On the one hand, the minor rivers of Kuzbass, which flow in the coal mining areas, are the resting place of the population, are fishery, on the other hand, they are receivers of wastewater from mining enterprises that have a significant impact on their condition. In this regard, state control over the use of water resources in the area of mining operations should be strengthened, and the enterprises should strive to introduce advanced scientific and technological developments in the field of environmental protection.

\section{References}

1. Overview of State Ownership in Global Minerals Industry (The World Bank Raw Materials Group, Wachington, 2011)

2. World Investment report (UNCTAD New York and Geneva, 2007)

3. China's outgoing funds change focus (Mining Outline, Geneva, 2010)

4. Mining Weekly (SABN, Johannesburg, 2007)

5. China Africa investment relations (Mining Outline, Geneva, 2010)

6. Canadian Mining (Mining Outline, Geneva, 2018)

7. D. Humphrey, Mineral Economics, 5, 110 (2018)

8. Coal Information. International Energy Agency Statistics (OECD/IEA, Birmingham, 2018)

9. Energy prices \& taxes 2000. International Energy Agency Statistics (Birmingham, OECD/IEA, 2018)

10. BP Statistical Review of World Energy June 2018 (BP, London, 2018) 